Syntax Literate : Jurnal Ilmiah Indonesia p-ISSN: 2541-0849

e-ISSN : 2548-1398

Vol. 5, No. 4 April 2020

\title{
BIAYA PENGELUARAN SENDIRI DAN PENGARUHNYA TERHADAP KESULITAN EKONOMI PASIEN HEMODIALISIS DI RUMAH SAKIT UMUM DAERAH KABUPATEN CIREBON
}

\author{
Meita Ayuditiawati, Shirly Kumala dan Prih Sarnianto \\ Universitas Pancasila Jakarta \\ Email: meitaayuditiawati@gmail.com,fskumala@yahoo.com dan \\ prih1488@gmail.com
}

\begin{abstract}
Chronic Kidney Disease (CKD) was a global public health problem with increasing prevalence and incidence, poor prognosis and high costs. In Indonesia therapy Chronic Kidney Disease (CKD) was the most preferred is hemodialysis. Hemodialysis therapy should be done regularly and long lasting as well as a lifetime of giving rise to an economic burden and own expenses.The purpose of this study was to determine the socio-demographic relationship with economic difficulties and determinants that can affect economic difficulties, the percentage of economic difficulties in CKD patients with hemodialysis therapy and the largest component of own expenses in Cirebon District Hospital.This study used a crosssectional non-experimental design with a purposive sampling. Primary data is obtained through patient interviews with structured questionnaires and secondary data from patient medical records. The research subjects were Hemodialysis patients in Cirebon District Hospital as many as 100 patients.The data were analyzed using logistic regression to identify the relationship between independent and dependent variables. Multivariate results showed that there was a significant relationship between the distance of the patient's house to the hospital OR 6.674 (1,444-30.85), patient income OR 0.164 (0.027-1,000), health expenses OR 0.206 (0.008-0.228) and hemodialysis duration OR $46.37(4,171-515,488)$ with economic difficulties.Patients with chronic kidney disease on hemodialysis economic hardship as a result of $68 \%$ and the largest component of the expenses itself are the cost of transport, eating and drinking at Rp.750.000/month which caused economic hardship in patients with CKD in RSUD Cirebon.
\end{abstract}

Keywords: Out Of Pocket Cost, Economic Difficulties, Hemodialysis, Cirebon District Hospital.

\footnotetext{
Abstrak

Terapi Penyakit Ginjal Kronik (PGK) yang paling banyak dipilih di Indonesia adalah hemodialisa. Hemodialisa harus dilakukan secara rutin dan berlangsung seumur hidup sehingga menimbulkan beban ekonomi dan biaya pengeluaran sendiri. Tujuan penelitian ini untuk mengetahui hubungan sosio-demografi dengan kesulitan ekonomi dan faktor penentu yang dapat mempengaruhi kesulitan ekonomi serta komponen terbesar biaya pengeluaran sendiri di RSUD Kabupaten Cirebon. Penelitian ini menggunakan rancangan non ekperimental secara potong lintang
} 
(Cross Sectional) dengan pengambilan sampel secara purposive sampling. Data primer diperoleh melalui wawancara pasien dengan kuisioner terstruktur dan data sekunder dari rekam medis pasien. Subyek penelitian adalah pasien Hemodialisa di RSUD Kabupaten Cirebon sebanyak 100 pasien. Data dianalisis menggunakan uji statistik untuk mengetahui hubungan antara variabel independen dan dependen. Hasil multivariat penelitian menunjukkan ada hubungan bermakna antara jarak rumah pasien ke rumah sakit OR 6,674 (1,444-30,85), pendapatan pasien OR 0,164 (0,027-1,000), pengeluaran kesehatan OR 0,206 (0,008-0,286) dan lama hemodialisa OR 46,37 (4,171-515,488) dengan kesulitan ekonomi. Pasien penyakit ginjal kronik mengalami kesulitan ekonomi akibat hemodialisis 68\%. Komponen biaya terbesar adalah biaya transport dan makan minum sebesar Rp.750.000/bulan yang menyebabkan kesulitan ekonomi pada pasien PGK di RSUD Kabupaten Cirebon.

Kata kunci : Biaya pengeluaran sendiri, kesulitan ekonomi, hemodialisis.

\section{Pendahuluan}

Menurut WHO pada tahun 2005, sekitar 58 juta kematian di seluruh dunia, dengan 35 juta disebabkan oleh penyakit kronis. Menurut studi Global Barden of Disease study 2010, PGK menduduki peringkat ke-27 dalam daftar penyebab jumlah kematian di seluruh dunia pada tahun 1990, namun meningkat menjadi 18 pada tahun 2010 (Foundation, 2015).

Penyakit ginjal kronik merupakan penyakit tidak menular tetapi dapat menimbulkan kematian. Untuk mempertahankan hidupnya, pasien gagal ginjal terutama yang kronik terminal (end stage renal disease) memerlukan terapi pengganti fungsi ginjal untuk memperpanjang harapan hidup pasien. Di Indonesia, hemodialisis merupakan metode pengganti fungsi ginjal yang paling sering digunakan (Jos, n.d.). Hemodialisis (HD) merupakan terapi pengganti fungsi ginjal yang menggunakan alat khusus dengan tujuan mengeluarkan toksis uremik dan mengatur cairan elektrolit tubuh (RI, 2017).

Perlindungan terhadap Pasien tertuang dalam pasal 3 UU No. 442009 yang menyatakan bahwa adanya rumah sakit bertujuan untuk memberikan kemudahan bagi masyarakat, menyediakan perlindungan bagi keselamatan pasien, meningkatkan mutu dan mempertahankan standar pelayanan rumah sakit serta memberikan kepastian hukum terhadap semua masyarakat dan SDM rumah sakit (Lambok \& Asyiafa, 2019). Sementara itu, pasien PGK dituntut untuk meningkatkan kualitas hidup dengan menjalani terapi HD secara rutin. Karena pengobatannya yang membutuhkan waktu lama, biaya tidak langsung yang harus ditanggung pasien dan keluarganya sangat besar. Hal ini dapat membuat pasien dan keluarganya mengalami kesulitan ekonomi, yaitu tidak mampu memenuhi kebutuhan pokok (primer) lainnya karena sumber daya keuangan banyak terpakai untuk pengobatan.

Rumah Sakit Umum Daerah di Wilayah Kabupaten Cirebon khususnya RSUD Arjawinangun dan Waled telah melaksanakan pelayanan hemodialisis kepada pasien PGK. Jumlah pasien Hemodialisis baik pasien baru maupun pasien yang telah 
mendapatkan hemodialisis pada tahun 2017 menunjukkan adanya peningkatan dari 42 orang menjadi 47 orang, dengan jumlah tindakan dari 342 tindakan menjadi 384 tindakan. Sedangkan berdasarkan cara pembayaran, pasien lebih dominan bahkan hampir seluruhnya menggunakan cara pembayaran BPJS.

Berdasarkan uraian diatas, maka penulis tertarik melakukan penelitian di RSUD Arjawinangun dan Waled. Penelitian ini bertujuan mengetahui besaran biaya yang harus ditanggung pasien dan keluarganya, serta faktor-faktor yang menentukan kesulitan ekonomi pada pasien PGK yang menjalani terapi HD.

\section{Metode Penelitian}

Penelitian yang digunakan termasuk non eksperimental secara potong-lintang (Cross Sectional) dilakukan pada pasien PGK stadium akhir yang menjalani hemodialisis di RSUD Kabupaten Cirebon pada Periode Juli-September 2018. Penulis akan meneliti kesulitan ekonomi sebagai variabel dependent dan sosio-demografi pasien dan informasi terkait dengan HD sebagai variabel independent. Dengan purposive sampling diperoleh sampel 100 orang terdiri 38 dari RSUD Arjawinangun dan 62 dari RSUD Waled.

Data sampel diperoleh melalui rekam medis, wawancara tatap muka dan kuesioner pada pasien PGK yang menjalani hemodialisis selama 3 bulan. Setelah data diperoleh, kemudian dilakukan analisis univariat, bivariat dan multivariat. Data univariat disajikan secara deskriptif analitik yaitu penjelasan hasil penelitian yang ditampilkan dalam bentuk tabel sedangkan untuk data analisis bivariat dan multivariat disajikan dengan hasil analisa statistik

\section{Hasil dan Pembahasan}

Karakteristik sosio-demografi pasien meliputi umur responden dengan rata-rata 50-59 tahun sebanyak 37 reponden (37\%). Jenis kelamin terbanyak laki-laki (51\%) dan tingkat pendidikan terbanyak sekolah menengah $60 \%$. Status perkawinan sebagian besar menikah (94\%) dan pekerjaan responden didominasi oleh pekerjaan fisik (52\%). Untuk status dalam rumah tangga, persentasenya seimbang antara kepala keluarga (KK) dengan bukan kepala keluarga (50\%). Mayoritas jumlah anggota keluarga 3-5 orang (54\%) dan jarak dari rumah ke rumah sakit terbanyak berjarak $>10 \mathrm{~km}$ (63\%). Pendapatan responden mayoritas (46\%) lebih dari 4 juta rupiah perbulan dimana responden sebagian besar (76\%) tinggal di rumah milik. Responden mayoritas menjadi peserta BPJS-K (56\%) dengan pengeluaran kesehatan responden terbanyak $(40 \%)$ berkisar 250-500 ribu rupiah per kedatangan. Lamanya pasien menjalani HD, paling banyak 5-10 tahun sebanyak 35\% dan responden mayoritas mengalami sakit hipertensi sebagai penyakit penyerta (74\%). Sebagian besar responden (68\%) mengalami kesulitan ekonomi akibat pengeluaran-pengeluaran karena penyakitnya. 
Tabel 1 Hasil uji bivariat dan multivariat awal pasien PGK

\begin{tabular}{lccc}
\hline \multicolumn{1}{c}{ Variabel } & $\begin{array}{c}\boldsymbol{p} \text {-Value } \\
*)\end{array}$ & $\begin{array}{c}\boldsymbol{p} \text { - Value } \\
* *)\end{array}$ & OR (95\% CI) \\
\hline Pendidikan & 0,01 & 0,619 & 1,352 \\
\hline Jumlah Anggota Keluarga & 0,045 & 0,560 & 1,643 \\
\hline Jumlah Tanggungan & 0,05 & 0,171 & 0,333 \\
\hline Jarak Rumah Ke RS & 0,00 & 0,028 & 0,342 \\
\hline Pendapatan Pasien & 0,00 & 0,020 & 3,629 \\
\hline Kepemilikan Rumah & 0,24 & 0,464 & 0,511 \\
\hline Pengeluaran Kesehatan & 0,00 & 0,007 & 4,681 \\
\hline Lama HD & 0,00 & 0,005 & 0,306 \\
\hline Komorbiditas & 0,11 & 0,075 & 0,327 \\
\hline Jenis kelamin & 0,57 & & \\
\cline { 1 - 1 } Status perkawinan & 0,00 & & \\
\hline Pekerjaan & 0,82 & & \\
\hline Kepesertaan BPJS & 0,64 & & \\
\hline Peran dalam rumah tangga & 0,67 & & \\
\hline Umur & 0,96 & & \\
\hline Keterangan : & & & \\
\hline
\end{tabular}

Keterangan :*) Hasil uji bivariat;

**) Hasil uji multivariat awal

Sumber : data sekunder tahun 2018

Analisis bivariat ditampilkan pada tabel 1 dengan hasil sebagai berikut; (1) Hubungan umur dengan kesulitan ekonomi didapat $p$-value 0,96 ; (2) hubungan jenis kelamin dengan kesulitan ekonomi didapat nilai $p$-value 0,57 ; (3) hubungan pendidikan dengan kesulitan ekonomi di dapat nilai p-value 0,00 ; (4) hubungan status perkawinan dengan kesulitan ekonomi didapatkan nilai $p$-value 0,00 ; (5) hubungan pekerjaan dengan kesulitan ekonomi diperoleh nilai $p$-value $0,82(>0,05)$; (6) hubungan status kepala keluarga dengan kesulitan ekonomi didapatkan nilai $p$-value 0,67 ; (7) hubungan jumlah anggota keluarga dengan kesulitan ekonomi didapatkan nilai $p$-value 0,$05 ;(8)$ hubungan jumlah tanggungan dengan kesulitan ekonomi dengan nilai $p$-value 0,05 ; (9) hubungan jarak yang ditempuh dari rumah ke rumah sakit dengan kesulitan ekonomi didapatkan nilai $p$-value 0,00 ; (10) hubungan pendapatan dengan kesulitan ekonomi didapat nilai $p$ value 0,050; (11) hubungan kepemilikan rumah dengan kesulitan ekonomi didapatkan nilai $p$-value 0,24; (!2) hubungan pengeluaran kesehatan dengan kesulitan ekonomi didapat nilai $p$-value 0,00 ; (13) hubungan kepesertaan BPJS-K dengan kesulitan ekonomi didapatkan nilai $p$-value 0,64 ; (!4) hubungan lama terapi HD dengan kesulitan ekonomi.didapatkan nilai $p$-value 0,00 dan; (15) hubungan penyakit komorbiditas dengan kesulitan ekonomi didapatkan nilai $p$-value 0,11 .

Untuk analisa selanjutnya terpilih 10 variabel dengan nilai $\mathrm{p}$ kurang dari 0,25 yaitu variabel pendidikan ( $p$-value 0,01$)$, status perkawinan ( $p$-value 0,00$)$, jumlah anggota keluarga ( $p$-value 0,045$)$, jumlah tanggungan ( $p$-value 0,05$)$, jarak ke rumah sakit ( $p$-value 0,00$)$, pendapatan paisen ( $p$-value 0,00$)$, kepemilikan rumah ( $p$-value 
$0,24)$, pengeluaran kesehatan ( $p$-value 0,00$)$, lamanya terapi $\mathrm{HD}(p$-value 0,00$)$ dan komorbiditas ( $p$-value 0,11 )

Hasil analisis multivariat awal pada tabel 1 diperoleh 4 variabel yang paling berhubungan dengan kesulitan ekonomi. Selanjutnya diuji dengan regresi logistik diperoleh seperti pada tabel 2. Variabel jarak ke rumah sakit 6-10 km (OR 2,90(0,58514,390)) dan jarak k rumah sakit > $10 \mathrm{~km}(\mathrm{OR} 6,674(1,444-30,850))$. Pendapatan pasien 2-4 juta $($ OR 0,43(0,026-0,501)) dan > 4 juta (OR 0,164(0,027-1,000)). Pengeluaran kesehatan >250 - 500 ribu $($ OR 0,047(0,004-0,963)) dan > 500 ribu (OR 0,206(0,008$0,268)$ ). Lamanya terapi HD $>3-5$ tahun (OR 11,771(1,145-120,982)), >5-10 tahun (OR $12,304(1,109-136,479))$ dan $>10$ tahun (OR 46,370(4,171-515,488)).

Tabel 2 Hasil Analisis Multivariat

\begin{tabular}{lllc}
\hline \multicolumn{1}{c}{ Variabel } & $\boldsymbol{p}$ - Value & OR & 95\% CI \\
\hline Jarak rumah ke rumah sakit & & & \\
$0-5 \mathrm{~km}$ & 0,047 & 1 & \\
$6-10 \mathrm{~km}$ & 0,193 & 2,900 & $(0,585-14,390)$ \\
$>10 \mathrm{~km}$ & 0,015 & 6,674 & $(1,444-30,850)$ \\
\hline Pendapatan Pasien & & & \\
$<2$ juta & 0,007 & 1 & \\
2-4 juta & 0,004 & 0,113 & $(0,026-0,501)$ \\
$>4$ juta & 0,050 & 0,164 & $(0,027-1,000)$ \\
\hline Pengeluaran Kesehatan & & & \\
0-250 ribu & 0,004 & 1 & \\
$>$ 250-500ribu & 0,001 & 0,047 & $(0,004-0,963)$ \\
$>500$ ribu & 0,045 & 0,206 & $(0,008-0,286)$ \\
\hline Lama HD & & & \\
1-3 tahun & 0,017 & 1 & \\
$>3-5$ tahun & 0,038 & 11,771 & $(1,145-120,982)$ \\
$>5-10$ tahun & 0,041 & 12,304 & $(1,109-136,479)$ \\
$>10$ tahun & 0,002 & 46,37 & $(4,171-515,488)$ \\
\hline Sumber $:$ data sekunder tahun 2018 & &
\end{tabular}

Sumber : data sekunder tahun 2018

Total biaya pengeluaran pasien PGK seperti pada tabel 3 dengan nilai Mean (rata-rata) Rp 195.069,4, Median Rp 200.000 dengan Standar Deviasi Rp 87.362,77 sehingga besar beban yang dikeluarkan pasien yang menjalani HD adalah minimum Rp 60.000 dan maksimum pengeluaran per kedatangan HD Rp 387.500. Biaya sendiri yang dikeluarkan pasien atau keluarganya meliputi; (1) biaya untuk transport dan makan minum minimal per kedatangan Rp 10.000 dan maksimal Rp 125.000; (2) biaya produktivitas yang hilang pasien HD per kedatangan minimal Rp 12.500 dan maksimal Rp 93.750; (3) biaya obat dan multivitamin minimum Rp 12.500 dan maksimum Rp 62.500; (4) biaya pendamping pasien (Care giver) minimum $\mathrm{Rp} 12.500$ dan maksimal Rp 62.500; (5) biaya Opportunity minimal per kedatangan HD sebesar Rp 12.500 dan maksimal Rp. 43.750. 
Tabel 3 Total biaya pengeluaran sendiri per kedatangan Hemodialisis secara keseluruhan

\begin{tabular}{|c|c|c|c|c|c|c|}
\hline & Count & Mean & Median & $\begin{array}{c}\text { Standar } \\
\text { Deviation }\end{array}$ & $\underset{\mathrm{m}}{\operatorname{Minimu}}$ & $\underset{\mathrm{m}}{\operatorname{Maximu}}$ \\
\hline $\begin{array}{l}\text { Transportasi, } \\
\text { makan dan } \\
\text { Minum }\end{array}$ & 100 & 70763,8889 & 93750,00 & 33931,7563 & 10.000 & 125000 \\
\hline $\begin{array}{l}\text { Produktif yang } \\
\text { hilang }\end{array}$ & 100 & 28298,6111 & 18750,0000 & 20292,8400 & 12500 & 93750 \\
\hline $\begin{array}{ll}\text { Obat } & \text { dan } \\
\text { multivitamin } & \text { non } \\
\text { BPJS } & \\
\end{array}$ & 100 & 27604,1667 & 25000,0000 & 12710,28478 & 12500 & 62500 \\
\hline $\begin{array}{l}\text { Biaya } \\
\text { pendamping } \\
\text { (Care giver) }\end{array}$ & 100 & 41666,6667 & 37500,000 & 9087,86475 & 12500 & 62500 \\
\hline Opportunity & 100 & 26736,1111 & 25000,0000 & 11340,02778 & 12500 & 43750 \\
\hline Total & 100 & 195069,4 & 200000 & 87362,77 & 60.000 & 387500 \\
\hline
\end{tabular}

Sumber : data sekunder tahun 2018

Dari karakteristik umur, dapat disimpulkan bahwa bertambah umur maka semakin banyak jumlah pasien HD. Hasil penelitian ini sesuai pernyataan bahwa prevalensi PGK akan meningkat seiring dengan bertambahnya umur (IRR), 2015). Sejalan pula dengan penelitian di Rumah Sakit Bethesda bahwa terjadi peningkatan jumlah pasien seiring dengan bertambahnya umur (Fauziah, Wahyono, \& Budiarti, 2015). Apabila dihubungkan umur dengan kesulitan ekonomi, tidak ada hubungan ( $p$ value 0,96>0,05). Hasil penelitian di Rumah Sakit Umum Bekasi menunjukkan hasil serupa yaitu tidak ada hubungan yang signifikan antara umur dengan gagal ginjal kronis (Sumiyati, 2018).

Besarnya angka kejadian gagal ginjal kronis yang dialami laki-laki karena pengaruh perbedaan hormon reproduksi dan gaya hidup yang kurang baik, seperti konsumsi alkohol, garam, rokok. Data prevalensi PGK pada laki-laki 0,3\% lebih tinggi daripada perempuan $0,2 \%$ (RI, 2017).

Berdasarkan hasil statistik di Kabupaten Cirebon, pasien laki-laki lebih banyak dibandingkan dengan pasien perempuan. Hal ini dikarenakan jumlah penduduk laki-laki pada tahun 2018 lebih banyak (105,17\%) dibandingkan dengan perempuan (Cirebon, 2018). Jika dihubungkan dengan kesulitan ekonomi didapat nilai ( $p$-value 0,57>0,05) yang artinya tidak ada hubungan. Hasil ini tidak sejalan dengan penelitian yang dilakukan di Indonesia dengan menggunakan data sekunder hasil riskesdas tahun 2013 terdapat hubungan yang bermakna antara jenis kelamin dengan kejadian PGK pada penderita hipertensi. Responden berjenis kelamin laki-laki berisiko 1,783 kali lebih besar terkena PGK dibandingkan dengan perempuan (Arifa, Azam, \& Handayani, 2017). 
Pendidikan responden terbanyak adalah sekolah menengah 60\%. Hasil ini berbeda dengan prevalensi yang tertinggi pada masyarakat dengan tidak bersekolah sebanyak 0,4\% (RI, 2017). Namun demikian, sejalan dengan penelitian di RSUD X pada karakteristik pendidikan terakhir pasien adalah sekolah menengah beresiko 0,5 kali daripada yang tidak sekolah atau sekolah dasar untuk mengalami HD (Rosiana, 2018). Dilihat dari nilai $p$-value $0,00(<0,05)$. terdapat hubungan yang signifikan antara pendidikan dengan kesulitan ekonomi. Menurut penelitian yang dilakukan di RSUD Kabupaten Sukoharjo, terdapat hubungan antara tingkat pendidikan dengan asupan cairan pada pasien gagal ginjal kronik yang menjalani hemodialisis. Ini menunjukkan bahwa semakin tinggi tingkat pendidikan seseorang maka pengetahuan seseorang akan semakin tinggi, sehingga pasien PGK akan menjaga kondisi kesehatannya (Umayah, 2016).

Penelitian yang dilakukan di Rumah sakit Mayo, Lahore menyatakan adanya hubungan yang signifikan antara pendidikan dengan kualitas hidup pada pasien PGK yang menjalani hemodialisis (Muhammad Anees, Shazia Batool, 2018). Pendidikan yang lebih tinggi pada pasien PGK yang menjalani hemodialisis mempunyai pengetahuan yang lebih luas sehingga memungkinkan pasien dapat mengontrol dirinya dalam mengatasi masalah yang dihadapi, mempunyai rasa percaya diri yang tinggi, berpengalaman dan mempunyai perkiraan yang tepat bagaimana mengatasi suatu kejadian (Yuliaw, 2009).

Kebanyakan pasien sudah menikah karena pasien HD berada pada range umur telah menikah. Hasil ini sejalan dengan penelitian pada tahun 2017 yang berjudul faktor yang berhubungan dengan kejadian penyakit ginjal kronik pada penderita hipertensi di Indonesia (Arifa et al., 2017). Hasil penelitian menyatakan bahwa proporsi responden berstatus menikah yang mengalami PGK lebih banyak $(84,7 \%)$ dibandingkan dengan status lainnya. Hubungan antara status perkawinan dengan kesulitan ekonomi didapatkan nilai $p$-value $0,00(<0,05)$. Ini menunjukkan ada hubungan yang signifikan antara status perkawinan dengan kesulitan ekonomi.

Hasil penelitian ini sejalan dengan penelitian di rumah sakit $X$ yang menganalisis faktor resiko dan komparatif biaya pengobatan pada pasien HD yang sudah menikah 2,6 kali lebih tinggi untuk mengalami PGK dibandingkan dengan mereka yang belum kawin tetapi tidak mempunyai pengaruh yang signifikan terhadap PGK (Rosiana, 2018).

Pekerjaan fisik (52\%) merupakan yang dominan dari responden. Hasil ini sejalan dengan penelitian yang dilakukan di rumah sakit umum Bekasi dengan studi CaseControl faktor resiko dan biaya tanggungan sendiri pasien gagal ginjal kronis di unit HD. Berdasarkan pekerjaan pasien kelompok kasus dan kontrol yang paling dominan adalah pekerjaan fisik sebanyak 54,7\% dan 50,7\% (Sumiyati, 2018). Adapun hubungan antara pekerjaan dengan kesulitan ekonomi diperoleh nilai $p$-value $0,82(>0,05)$ Ini menunjukkan tidak adanya hubungan yang signifikan antara status pekerjaan dengan kesulitan ekonomi. Pada kenyataannya pekerjaan akan berpengaruh pada frekuensi dan distribusi penyakit, sehingga menurut peneliti pekerjaan ini mempunyai hubungan yang 
signifikan dengan keadaan ekonomi atau kesulitan ekonomi akibat hemodialisis. Responden yang hemodialisis akan sulit melakukan aktivitas atau berkurang (Ahmad \& Utarini, 2013).

Responden hemodialisis dalam keluarga berstatus sebagai kepala keluarga dan sebagai penanggung jawab utama perekonomian keluarga. Akibat dari PGKnya, responden mengalami penurunan kualitas hidup sehingga akan berpengaruh terhadap pendapatan keluarga dan penurunan ekonomi. Namun dari uji statistik hubungan antara status kepala keluarga dengan kesulitan ekonomi didapatkan nilai $p$-value $0,67(>0,05)$ menunjukkan tidak ada hubungan yang signifikan antara status kepala keluarga dengan kesulitan ekonomi. Hasil penelitian ini sesuai dengan penelitian yang dilakukan di rumah sakit umum kota Bekasi bahwa tidak ada hubungan yang signifikan antara status pasien dalam keluarga dengan kesulitan ekonomi (36). Status pasien dalam keluarga (70\%) merupakan kepala keluarga, dalam hal ini merupakan tulang punggung keluarga dan sebagai tulang punggung perekonomian keluarga. Pada kelompok umur ini merupakan umur yang produktif dalam menjalankan tugas-tugas pelayanan bagi masyarakat. Penyakit PGK ini merupakan salah satu penyakit yang dapat membebani pasien, keluarga dan masyarakat, oleh karena itu kondisi seperti ini harus mendapatkan perhatian lebih banyak.

Mayoritas responden memiliki jumlah anggota keluarga 3-5 orang (54\%). Hal ini karena masyarakat Kabupaten Cirebon masih mempercayai budaya semakin banyak anggota keluarga akan semakin banyak juga rejekinya dan rumah tidak akan sepi. Dari data statistik, Kabupaten Cirebon merupakan salah satu kabupaten yang mempunyai jumlah penduduk yang cukup besar. Penduduk Kabupaten Cirebon pada tahun 2014 adalah 2.293.397 jiwa (Cirebon, 2018). Berdasarkan hasil uji statistik hubungan antara jumlah anggota keluarga dengan kesulitan ekonomi didapatkan nilai $p$-value 0,05 $(\leq 0,05)$ hal ini menunjukkan ada hubungan yang signifikan antara jumlah anggota keluarga dengan kesulitan ekonomi.

Jumlah tanggungan responden yang terbanyak adalah mempunyai tanggungan keluarga (95\%). Jumlah tanggungan ini merupakan anggota keluarga responden yang berusia kurang dari 15 tahun dan lebih dari 65 tahun. Penelitian ini sejalan dengan penelitian (36) yang menyatakan bahwa tanggungan keluarga pasien PGK yang menjalani terapi HD yang tidak mempunyai tanggungan $5 \%$. Terdapat hubungan antara jumlah tanggungan dengan kesulitan ekonomi dengan nilai $p$-value $0,05(\leq 0,05)$, Semakin banyak tanggungan dalam keluarga semakin banyak pengeluaran sehingga menyebabkan kesulitan ekonomi. Anggota keluarga yang menjadi tanggungan keluarga adalah anggota keluarga yang berusia kurang dari 15 tahun dan lebih dari 65 tahun.

Rata-rata pasien berasal dari luar Arjawinangun dan Waled sehingga jaraknya jauh dari rumah ke RSUD Arjawinangun dan RSUD Waled dan kendaraan yang digunakan rata-rata menggunakan kendaraan umum pada jalur transportasi darat seperti ojek dan mobil angkot. Hasil penelitian ini sejalan dengan penelitian yang dilakukan di rumah sakit umum Bekasi yang menyatakan bahwa jarak yang harus ditempuh pasien hemodialisis untuk mengakses fasilitas rumah sakit yang paling banyak yaitu jarak $>10$ 
km (Sumiyati, 2018). Hasil uji statistik hubungan antara jarak yang ditempuh dari rumah ke rumah sakit dengan kesulitan ekonomi didapatkan nilai $p$-value $0,00(\leq 0,05)$. Hal ini menunjukkan ada hubungan yang signifikan antara jarak yang ditempuh dari rumah ke rumah sakit dengan kesulitan ekonomi. Rata-rata pasien berasal dari luar Arjawinangun dan Waled sehingga jaraknya jauh dari rumah responden ke RSUD Arjawinangun dan RSUD Waled. Jalur transportasi darat merupakan satu-satunya jalur yang ditempuh dan kendaraan yang digunakan rata-rata menggunakan kendaraan umum pada jalur transportasi darat seperti ojek dan mobil angkot. Hasil penelitian ini sejalan dengan penelitian yang dilakukan di Rumah sakit umum Bekasi yang menyatakan bahwa jarak yang harus ditempuh pasien hemodialisis untuk mengakses fasilitas rumah sakit yang paling banyak yaitu jarak > $10 \mathrm{~km}$ (Sumiyati, 2018). Hasil penelitian ini sesuai dengan penelitian yang dilakukan di Rumah Sakit Umum Daerah Tipe B di Provinsi Bali yang menganalisis peserta asuransi menurut perspektif pasien menyatakan bahwa faktor jarak rumah pasien ke RS mempengaruhi biaya hemodialisis yang ditanggung pasien (45). Faktor jarak rumah pasien ke RS ini menjadi beban ekonomi pasien hemodialisis sehingga akan mempengaruhi pada kesulitan ekonomi. Dapat disimpulkan pula bahwa berdasar hasil uji multivariat, pasien HD dengan jarak dari rumah ke rumah sakit>10 $\mathrm{km}$ sebesar 6,7 kali lebih besar berpotensi mengalami kesulitan ekonomi dibandingkan dengan jarak ke rumah sakit yang jaraknya 0-5 km dan 6-10 km. Dengan nilai $p$ value $0,015(<0,05)$ menunjukkan jarak rumah ke rumah sakit ada hubungan yang signifikan dengan kesulitan ekonomi. Menempuh jarak >10 $\mathrm{km}$ pasien HD dapat mengalami kesulitan ekonomi adalah pasien yang tergolong menengah ke bawah dengan pendapatan yang rendah karena jarak tempuh dari rumah ke rumah sakit terkait dengan bahan bakar yang digunakan sehingga dapat menyebabkan kesulitan ekonomi.

Pendapatan pasien perbulan didapatkan dari bisnis keluarga, gaji, sopir kendaraan umum, buruh pabrik, buruh tani dan pemberian/kiriman dari keluarga. Responden sebagian besar (76\%) tinggal di rumah dengan status kepemilikan milik sendiri tetapi ada juga masih menyicil. Tempat tinggal merupakan kebutuhan primer yang prioritas dan merupakan aset atau harta yang paling berharga yang dapat menggambarkan kesejahteraan sesorang. Berdasarkan uji statistik hubungan antara pendapatan responden dengan kesulitan ekonomi didapatkan nilai $p$-value 0,00. Hal ini menunjukan adanya hubungan yang signifikan antara pendapatan responden dengan kesulitan ekonomi. Pendapatan responden yang berbeda dalam penelitian ini merupakan prediktor yang signifikan terhadap biaya yang ditanggung pasien disaat menjalani hemodialisis, pasien yang penghasilannya 2-4 juta menghabiskan biaya hemodialisis lebih besar. Hasil penelitian ini sejalan dengan penelitian yang dilakukandi Rumah sakit Mayo, Lahore yang menyatakan adanya hubungan yang signifikan antara sosio ekonomi pendapatan dengan kualitas hidup pada pasien PGK yang menjalani hemodialisis. Pendapatan lebih tinggi memiliki status pekerjaan yang lebih baik sehingga pasien yang menjalani hemodialisis tidak mengalami kesulitan ekonomi. Hasil uji mutivariat menunjukkan bahwa pendapatan pasien HD dengan nominal > Rp 4.000 .000 akan 
mengalami 0,2 kali lebih rendah kesulitan ekonomi dibandingkan dengan pasien yang memiliki pendapatan < Rp 2.000.000 dan Rp 2.000.000 - Rp 4.000.000. Dengan nilai $p$ value 0,050, menunjukan adanya hubungan antara pendapatan dengan kesulitan ekonomi dan berdasar nilai OR diperoleh OR 0,164 (<1). Hal ini menunjukkan bahwa pendapatan bukan sebagai faktor penentu penyebab kesulitan ekonomi, tetapi sebagai faktor protektif dari kesulitan ekonomi khususnya dari pengeluaran kesehatan.

Berdasarkan hubungan kepemilikan rumah dengan kesulitan ekonomi didapatkan nilai $p$-value 0,24 . Hal ini menunjukkan tidak ada hubungan yang signifikan antara kepemilikan rumah dengan kesulitan ekonomi. Dengan adanya kepemilikan rumah maka keluarga akan sejahtera dan memberikan ketahanan hidup dibandingkan dengan yang tidak memiliki rumah.

Berdasarkan nilai $p$-value 0,00 , menunjukan ada hubungan yang signifikan antara pengeluaran kesehatan dengan kesulitan ekonomi. Pengeluaran kesehatan yang tidak ditanggung oleh BPJS Kesehatan merupakan beban bagi pasien HD sehingga pasien harus berhutang sampai kondisi menjual barang-barang untuk mengantisipasi biaya-biaya yang harus ditanggung. Dengan demikian pengeluaran kesehatan pada pasien hemodialisis dapat mempengaruhi kesulitan ekonomi. Pasien dengan pengeluaran kesehatan > 250-500 ribu dan > 500 ribu per kedatangan, memperoleh nilai $\mathrm{OR}=0,047$ dan 0,206 $(<1)$. Dengan demikian pengeluaran kesehatan bukan merupakan faktor penentu kesulitan ekonomi tetapi hanya sebagai protektif, artinya dengan penghasilan yang lebih tinggi akan menjadi faktor protektif dari kesulitan ekonomi.

Kepesertaan responden (56\%) pada BPJS Kesehatan sejalan dengan data report of indonesian renal registry (IRR) yang menyatakan bahwa pendanaan pasien lebih banyak berasal dari JKN non PBI sebanyak 77\% dibandingkan dengan pendanaan pasien yang berasal dari JKN PBI sebanyak 13\% (IRR), 2015). Dengan adanya BPJS Kesehatan dapat meringankan biaya yang dikeluarkan pasien HD. Hemodialisis tanpa menggunakan BPJS menyebabkan pengeluaran kesehatan akan semakin banyak yang harus ditanggung pasien PGK untuk hemodialisis. Pengeluaran kesehatan yang harus ditanggung oleh pasien HD yang paling banyak adalah biaya transportasi, makan dan minum setiap kali HD. Dari hasil uji statistik hubungan antara kepesertaan BPJS Kesehatan dengan kesulitan ekonomi didapatkan nilai $p$-value 0,64(>0,05). Hal ini menunjukkan tidak ada hubungan yang signifikan antara kepesertaan BPJS Kesehatan dengan kesulitan ekonomi.

Lamanya menjalani HD dapat mempengaruhi kualitas hidup pasien PGK yang menjalani hemodialisis. Penelitian ini menunjukan yang paling banyak menjalani HD yaitu > 5-10 tahun. Hal ini dikarenakan pasien merasa kualitas hidupnya meningkat jika melakukan hemodialisis secara rutin dengan menjalani pola makan (diet) dan gaya hidup yang baik. Pasien yang sudah lama menjalani terapi HD, kualitas hidupnya meningkat karena pasien sudah beradaptasi terhadap terapi HD yang dijalani baik secara fisik maupun psikologis. Hasil uji statistik hubungan antara lama terapi HD dengan kesulitan ekonomi didapatkan nilai $p$-value $0,00(<0,05)$. Hal ini menunjukan adanya 
hubungan yang signifikan antara lama terapi HD dengan kesulitan ekonomi. Lamanya HD pasien akan semakin terbebani dengan biaya-biaya yang harus dikeluarkan selama terapi HD terutama biaya yang harus dikeluarkan dari kantongnya sendiri. Hal ini akan menimbulkan suatu masalah salah satunya adalah kesulitan ekonomi. Berdasar hasil uji multivariat lama HD > 10 tahun akan berpotensi mengalami kesulitan ekonomi lebih besar 46,37 kali dibandingkan dengan lama HD > 5-10 tahun yaitu 12,30 kali lebih besar mengalami kesulitan ekonomi dibandingkan dengan pasien yang menjalani HD selama 3-5 tahun. Lama HD akan berpotensi mengalami kesulitan ekonomi karena pembiayaan pasien hemodialisis yang menjalani terapi HD > 3 tahun akan semakin banyak menggunakan biaya sendiri untuk membiayai HD diluar pembiayaan BPJS Kesehatan. Semakin lama pasien menjalani terapi HD ini akan semakin besar mengalami kesulitan ekonomi karena semakin besar juga pengeluaran pembiayaan untuk kesehatan, transport, dan konsumsi. Terapi hemodialisis adalah salah satu penyelamatan pasien penyakit gagal ginjal kronik. Pada pasien PGK harus melakukan terapi hemodialisis sepanjang hidupnya untuk menambah dan memperpanjang usia pasien (Setyawan, 2018). Semakin lama menjalani HD maka kelangsungan hidupnya akan semakin baik, jika pasien mengikuti diet dengan baik, melaksanakan perubahan gaya hidup dan pengobatan yang sesuai dengan rekomendasi pelayanan kesehatan. Pada penelitian KSGH Rasyida medan menyatakan ada hubungan antara lama hemodialisis dengan kematian pasien PGK. Pada hasil multivariat, setelah dilakukan penyesuaian ternyata harapan hidup pasien menjalani HD lebih dominan dipengaruhi oleh lamanya HD dan adanya diabetes.

Sebagian besar (74\%) responden memiliki penyakit penyerta yaitu hipertensi. Hal ini sejalan dengan penelitian yang dilakukan di rumah sakit umum Bekasi yaitu komorbid yang paling banyak adalah 1 penyakit 41,3\% (Sumiyati, 2018) serta penelitian di rumah sakit PKU Muhammadiyah Yogyakarta yaitu responden yang memiliki komorbid hipertensi yang paling banyak $74,7 \%$ dari 70 pasien HD dibandingkan dengan komorbid diabetes dan jantung (Utami, Rosa, \& Khoiriyati, 2017). Hipertensi merupakan salah satu faktor resiko yang dominan penyakit ginjal kronik. Komorbiditas adalah kondisi atau penyakit lain selain PGK yang mempengaruhi organ lain, tetapi juga dapat menyebabkan gagal ginjal. Komorbid dapat berdampak buruk terhadap pasien hemodialisis (Braga et al., 2011). Pada penelitian ini penyakit penyerta pada pasien HD adalah hipertensi karena prevalensi hipertensi $(17,18 \%)$ di Jawa Barat tertinggi adalah di Kabupaten Cirebon dibandingkan dengan kabupaten lainnya di Jawa Barat (Cirebon, 2018). Hasil uji statistik menunjukan hubungan antara penyakit komorbiditas dengan kesulitan ekonomi didapatkan nilai $p$-value $0,11(>0,05)$. Ini menunjukan tidak ada hubungan yang signifikan antara penyakit komorbiditas dengan kesulitan ekonomi. Pada penelitian ini komorbiditas tidak mempengarui kesulitan ekonomi karena responden yang paling banyak mempunyai kormobiditas 1 (satu) penyakit yaitu hipertensi

Total biaya pengeluaran pasien PGK seperti pada tabel 3 dengan nilai Mean (rata-rata) Rp 195.069,4, Median Rp 200.000 dengan Standar Deviasi Rp 87.362,77 
sehingga besar beban yang dikeluarkan pasien yang menjalani HD adalah minimum Rp 60.000 dan maksimum pengeluaran per kedatangan HD Rp387.500.

Biaya sendiri yang dikeluarkan pasien atau keluarganya meliputi; (1) biaya untuk transport dan makan minum minimal per kedatangan Rp 10.000 dan maksimal Rp 125.000. Dengan kunjungan 8 (delapan) kali perbulan, maka total biaya transport dan makan minum minimal Rp 80.000 dan maksimal Rp 1.000 .000 per bulan; (2) biaya produktivitas yang hilang pasien HD per kedatangan minimal Rp 12.500 dan maksimal Rp 93.750 dihitung per hari dengan membagi penghasilan pasien dalam satu bulan dengan jumlah hari yang digunakan untuk terapi HD; (3) biaya obat dan multivitamin adalah Rp 27.604,1667 dengan biaya yang paling rendah Rp 12.500 dan paling banyak Rp 62.500 per kedatangan; (4) biaya pendamping pasien (Care giver). Dikarenakan kebanyakan pasien didampingi oleh keluarganya sendiri sehingga biaya pendamping ini dihitung dari biaya yang hilang paling rendah Rp 12.500 dan maksimal biaya Rp 62.500 dengan rata-rata biaya Rp 41.666,6667 per kedatangan; (5) biaya Opportunity adalah biaya yang dikeluarkan akibat pengambilan suatu pilihan yang mengorbankan pilihan lainnya, total rata-rata biaya Opportunity pada penelitian ini adalah Rp 195.069,4 dengan minimal per kedatangan HD sebesar Rp 12.500 dan maksimal Rp 43.750.

Pengeluaran kesehatan pada penyakit katastropik (PGK) merupakan ancaman penurunan kemampuan keuangan rumah tangga. Pasien kasatstropik hampir 2,3 juta individu (1\%) tiap tahunnya jatuh ke dalam kemiskinan sebagai dampak dari biaya kesehatan katastropik. Pada studi evaluasi ekonomi di Rumah Sakit kelas B dan C di unit $\mathrm{HD}$, responden mengaku harus membayar sebagian biaya yang tidak ditanggung BPJS, seperti biaya vitamin, obat yang tidak terkait dengan penyakit GGK atau HD ataupun obat yang atas keinginan pasien sendiri (Tania \& Thabrany, 2016).

Organisasi kesehatan dunia (WHO) menyatakan alokasi anggaran untuk kesehatan yang ideal adalah sekurang-kurangnya 6\% dari anggaran belanja negara (APBN). Di Indonesia anggaran untuk Departemen Kesehatan kurang dari 5\% dari APBN. Melihat karakteristik tersebut, maka biaya yang timbul akibat gangguan kesehatan (penyakit) merupakan obyek yang layak diasuransikan untuk meringankan beban yang ditanggung oleh penderita serta meningkatkan akses pelayanan kesehatan yang merupakan kebutuhan hidup masyarakat (Setyawan, 2018).

Di Indonesia saat ini 70\% mekanisme pembiayaan kesehatan berasal dari pihak swasta hanya $30 \%$ nya berasal dari pemerintah. Dari $70 \%$ pembiayaan tersebut, sebagian besar berasal dari kantong masyarakat sendiri (out of pocket cost) yang kita kenal dengan istilah Fee For Service dan hanya sekitar 6\% yang berasal dari asuransi (Tarigan \& Suryanti, 2017). Beban biaya pengeluaran sendiri yang paling dominan adalah biaya transportasi, makan dan minum pasien dan keluarganya selama terapi HD.

\section{Kesimpulan}

Berdasarkan hasil uji chi square dengan $p$ value $<0,05$ yang artinya ada hubungan yang signifikan antara pendidikan, status perkawinan, pekerjaan, jumlah anggota keluarga, jumlah tanggungan, jarak rumah ke rumah sakit, pendapatan pasien, 
kepemilikan rumah, pengeluaran kesehatan, lama HD dan kormobiditas dengan kesulitan ekonomi. Hasil analisis lanjut diperoleh kesulitan ekonomi yang dialami pasien HD RSUD Kabupaten Cirebon, secara signifikan dipengaruhi oleh 4 (empat) faktor yaitu jarak rumah ke rumah sakit OR 6,674 (1,444-30,85), pendapatan pasien OR 0,164 (0,027-1,000), pengeluaran kesehatan OR 0,206 (0,008-0,286) dan lama hemodialisa OR 46,37 (4,171-515,488). Pasien HD yang mengalami kesulitan ekonomi adalah sebanyak $68 \%$ dimana komponen terbesar biaya pengeluaran sendiri pada pasien PGK dengan HD adalah biaya transport, makan dan minum dengan median Rp 93.750 per kedatangan atau $\mathrm{Rp} 750.000$ per bulan.

Bagi masyarakat diharapkan lebih menjaga pola hidup dalam meningkatkan kesehatan ginjal terutama pada masyarakat yang mempunyai faktor resiko terjadinya PGK. Perlu dilakukan penelitian lebih lanjut perhitungan biaya pengeluaran sendiri yang dapat mempengaruhi kualitas hidup pasien hemodialisis. 


\section{BIBLIOGRAFI}

(IRR), I. R. R. (2015). 8th Report of Indonesian Renal Registry 2015. Jakarta: Perhimpunan Nefrologi Indonesia (PERNEFRI).

Ahmad, G. N. C. W. R. A., \& Utarini, A. (2013). Biaya Pelayanan Hemodialisis Peserta Asuransi Kesehatan Menurut Perspektif Pasien Di Rumah Sakit Umum Daerah Tipe B, Provinsi Bali. Jurnal Manajemen Pelayanan Kesehatan, 16(01).

Arifa, S. I., Azam, M., \& Handayani, O. W. K. (2017). Faktor yang berhubungan dengan kejadian penyakit ginjal kronik pada penderita hipertensi di Indonesia. Media Kesehatan Masyarakat Indonesia Universitas Hasanuddin, 13(4), 319-328.

Braga, S. F. M., Peixoto, S. V., Gomes, I. C., Acurcio, F. de A., Andrade, E. I. G., \& Cherchiglia, M. L. (2011). Factors associated with health-related quality of life in elderly patients on hemodialysis. Revista de Saude Publica, 45, 1127-1136.

Cirebon, B. P. S. K. (2018). Sensus Penduduk Online.

Fauziah, F., Wahyono, D., \& Budiarti, L. E. (2015). Cost of illness dari chronic kidney disease dengan tindakan hemodialisis. Jurnal Manajemen Dan Pelayanan Farmasi (Journal of Management and Pharmacy Practice), 5(3), 149-158.

Foundation, N. K. (2015). Global Facts : Kidney Disease.

Jos, W. (n.d.). Kualitas Hidup Pasien yang Menjalani Hemodialisis Rutin di RSUD Tarakan, Kalimantan Utara, 2014.

Lambok, B. D., \& Asyiafa, A. P. (2019). Pertanggungjawaban Hukum Tenaga Medis Dalam Tindakan Pemasangan Alat Pernapasan Lewat Mulut (Ventilator) Pada Pasien di Rumah Sakit. Syntax Literate; Jurnal Ilmiah Indonesia, 4(12), 74-86.

Muhammad Anees, Shazia Batool, M. I. dan M. I. (2018). Socio-economic factors affecting quality of life of Hemodialysis patients and its effects on mortality. Pakistan Journal Medical Science. https://doi.org/10.12669/pjms.344.15284

RI, K. K. (2017). Situasi Penyakit Ginjal Kronis. Jakarta: Kementrian Republik Indonesia.

Rosiana. (2018). Analisis Faktor Risiko dan Komparatif Biaya Pengobatan Penyakit Ginjal Kronis pada Pasien Hemodialisis di RS X.

Setyawan, F. E. B. (2018). Sistem Pembiayaan Kesehatan. Jurnal Berkala Ilmiah Kedokteran Dan Kesehatan, 2(4).

Sumiyati, Y. (2018). Studi case-control Faktor Resiko dan BiayaTanggungan Sendiri Pasien Gagal ginjal Kronis di Unit Hemodialisis Rumah Sakit Umum Kota Bekasi. Jakarta. 
Tania, F., \& Thabrany, H. (2016). Biaya dan Outcome Hemodialisis di Rumah Sakit Kelas B dan C. Jurnal Ekonomi Kesehatan Indonesia, 54.

Tarigan, I., \& Suryanti, T. (2017). Gambaran Out of Pocket pada Awal Era JKN di Indonesia. Jurnal Penelitian Dan Pengembangan Pelayanan Kesehatan, 1(2), $141-146$.

Umayah, E. (2016). Hubungan Tingkat Pendidikan, Pengetahuan dan Dukungan Keluarga Dengan Kepatuhan Dalam Pembatasan Asupan Cairan Pada Pasien Gagal Ginjal Kronik yang Mejalanii Hemodialisa Rawat Jalan di RSUD Sukoharjo. Universitas Muhammadiyah Surakarta.

Utami, M. P. S., Rosa, E. M., \& Khoiriyati, A. (2017). Gambaran Komorbid Pasien Hemodialisa (Comorbid in Hemodialysis Patients). Indonesian Journal of Nutritional Epidemiology and Reproductive, 6(1).

Yuliaw, A. (2009). Hubungan karakteristik individu dengan kualitas hidup dimensi fisik pasien gagal ginjal kronik di RS Dr. Kariadi Semarang. Diakses Daridigilib. Unimus. Ac. Id/Files/Disk1/106/Jtpunimus-Gdl-Annyyuliaw-5289-2-Bab2. Pdf Pada Tanggal, 29. 